\title{
SYMBOLS OF HEROES IN THE INDONESIAN AND CHINESE MOVIES
}

\author{
Woro Januarti* \\ College of Chinese Language and Literature, Wuhan University \\ No. 299 Bayi Road, Wuchang District, Wuhan City, Hubei Province, PR China, 430072 \\ aq_woro@yahoo.com
}

Received: $21^{\text {st }}$ January $2021 /$ Revised: $15^{\text {th }}$ April 2021/Accepted: $19^{\text {th }}$ April 2021

How to Cite: Juanuarti, W. (2021). Symbols of heroes in the Indonesian and Chinese movies. Lingua Cultura, 15(1), 29-38. https://doi.org/10.21512/lc.v15i1.6969

\begin{abstract}
The research aimed to compare a movie with the theme of heroes from Indonesia and China concerning message related to heroes, hero images, ideology, and even heroic culture of the two countries. It explored 20 Indonesian and Chinese films with comparative literary perspectives related to the theme of heroism. The focuses of the research were (1) how could the image of the hero created by the film provide a view of each country's people's culture, (2) could the movies provided more detailed information on the policies of each country, and (3) how could films strengthen the relationship between Indonesia and China. The research applied a qualitative methods with a comparative literature perspective. The data source were from the dialogues in the film "Merah Putih", "Gie", "Susi Susanti", "Soekarno", "Tanah Surga Katanya”, "3 Srikandi", "Laskar Pemimpi”, “Guru Bangsa”, “Soegija”, “Jenderal Soedirman”, 攀登者 (The Climbers), 中国机长 (The Captain), 红海行动 (Operation Red Sea), 烈火英雄 (The Bravest), 战狼 1 (Wolf Warrior 1), 战狼 2 (Wolf Warrior 2), 建国大业 (The Founding of A Republic), 建党大业 (Beginning of The Great Revival), 建军大业 (The Founding of An Army), and 叶问 (IP Man). Data analysis technique were conducted by (1) determining variables, (2) classification, (3) analysis, and (4) conclusions. The results show that the symbols of heroism in Indonesian and Chinese films have similarities to the fight against colonialism, injustice, and class. The theme of heroism in the two countries'films has a striking differences, such as Chinese films are more concerned with collective characters' obligations and interests, the film does not have an element of humor, and the theme emphasizes conflicts with other countries. While Indonesia films highlight individual characters'views and movies still include comedy and emphasize domestic problems.
\end{abstract}

Keywords: Indonesia movie, Chinese movie, heroic symbol, comparative literature

\section{INTRODUCTION}

The representation of heroes in literature is an age-long endeavor. Since ancient times, Indonesia and China have had a long history of seeing heroes. Indonesian heroes come from thousands of famous islands in the archipelago, making the perspective of heroes diverse. The diversity of the image of a hero for the Indonesian continues to change over time. As in the days of colonialism, heroes are considered figures who dare to fight the invaders, who dare to sacrifice themselves, warriors of religion, and freedom fighters. After the independence period, a hero's image is a figure who can make Indonesia proud in the international arena and carry out development.

In China itself, heroism begins with a flood disaster that 大禹 $(\mathrm{Da} \mathrm{Yu}$ ) can drive away ( $\mathrm{Da} \mathrm{Yu}$ Dispelling Flood). Therefore, initial heroism is originated from the war of resistance against foreign countries and nature (Hui, 2018). The heroes who continue told verbally become one of the Gods in Chinese society (Fan \& Yuanyuan, 2019), namely 黄 大仙 (God of Religion Dao), 关羽 (God of War), 秦 琼 (God of Door), 包拯 (Judge Bao). In the struggle against foreign invaders, feudal landlords, and bourgeoisie, countless heroes sacrifice their lives to save the people and the country from danger. They integrate their personal beliefs into the national will and stand up for the people again and again in danger.

This kind of loyal patriotism and indomitable perseverance becomes the heroic spirit's strong connotation (Jingwei \& Peiyu, 2020). After independence, when society has achieved prosperity, being a hero for the Chinese community is becoming a figure who can make China proud abroad, creator of new technology, guardian of China's dignity, and 
even a savior in all disasters in China. Countless heroes sacrifice their lives to save the people and the country from danger. Heroic spirit for Chinese people is people's heroes and national heroes based on heroic values, spiritual system, and value system centered on heroic values. It is the total heroic concept, heroic behavior, heroic achievements, and heroic values (Yong, 2019). Therefore, the concept of heroism that continues to change from generation to generation, both in China and Indonesia, is essentially no different in popular discourse and modern interpretations of heroes and celebrities. Celebrities and sports stars are often considered media heroes. After a disaster, the people who save and rebuild communities are also considered heroes (Azri \& Agung 2017).

The concept of superhuman ideas originated from legends and myths has been transformed into a popular culture that develops in society (Saptanto \& Dewi, 2020). From these stories of heroism (superhuman) since ancient times, the two countries' performing arts have been adorned. For examples are puppet shows, wayang golek, shadow puppets, ronggeng dance performances, Beijing opera, traveling storytellers, and in line with technological advances in 1895 , performing arts in the form of hero-themed films have emerged to entertain people around the world. The film, apart from being a historical record, also a cultural product (Bo \& Fei, 2019), and with visual power (movies), is capable of building one's perception through design elements on visual character (Pratama, Wardani, \& Akbar, 2017). Moreover, art's ultimate goal is to express people's feelings and thoughts, so is the film (Chao, 2019).

In Indonesia itself, cultural records through movies first showed in 1900 with establishing the first cinema in Indonesia in the Tanah Abang area, Batavia (Jakarta). In 1950, the Indonesian film industry was held by natives Usmar Ismail produced the film Darah dan Doa. It is claimed to be the first milestone in establishing the Indonesian film industry (Putri, Nuraeni, \& Syahriar, 2017). At the beginning of its appearance, Indonesian films had the theme of local stories such as Loetoeng Kasarung, the development of the forced marriage of Lily Van Java. In China, films first appeared in 1896. Many traders from various countries came to Shanghai, a merchant from America who brought films screened in Shanghai. The first film, which was a local production, was 《定军山》(Dingjun Mountain), a film adapted from the story 《三国演义》(The Three Kingdoms), which often performed in the Beijing opera stage play.

The word 'hero' according to the KBBI is a person who stands out because of his/her courage and sacrifice in defending the truth; valiant warrior; hero, while the word 'heroism' is defined the character of a hero, such as courage, willingness to sacrifice, and chivalry (Sunendar, 2016). In China, a hero is an ordinary person who has a tremendous patriotic heart and turns into firm patriotic action (Bin, 2020). According to the Chinese online dictionary Per Letter 汉语大辞典, the hero is an unusual character, a character whose idea, ability, exceeds the crowd or becomes a leader for many people 非凡出众的人物。指见解、才能超群 出众或领袖群众的人” (hyded.com). According to the Chinese online Word Dictionary 《现代汉语大词 典》, the hero is a character whose ability and courage surpass the crowd 才能勇武过人的人. According to Modern Chinese Dictionary $7^{\text {th }}$ edition 《现代汉语词 典》the meaning of heroes is (1) a Chinese man of great ability and brave than common people 本领高 强、勇武国人的人, (2) not afraid of difficulties, not thinking of himself, fighting bravely for the sake of the people, a respected person 不怕困难, 不顾自 己，为人民利益而英勇斗争，令人钦敬的人，

having the quality of being a hero 具有英雄的品质 的. According to the Complete Dictionary 《辞海》, a hero is an active attitude to complete tasks and show courage, strength, and sacrifice 主动为完成具有重大 意义的任务而表现出来的英勇、顽强和自我牺牲 气概和行为 (Yigu, 2016). In the final analysis, these are the manifestations of altruism and collectivism. Inspired by this spirit, it is worth affirming that individual interests give way to social interests and national interests (Jingjing \& Hua, 2018).

From the two countries' definitions can be seen the differences in seeing a hero's image. For the people of Indonesia, everyone can become a hero, both personally and as a representative of a community or group, as long as he/she can defend the truth, be brave, has a mighty nature, want to sacrifice, and is like a knight. For the Chinese people, being a hero is not a personal matter but is a task of the group, accompanied by an attitude of completing tasks with courage, strength, and sacrifice. Second, after understanding the meaning of the two countries' heroes, comparative literary theory is used as a weapon to understand the similarities and differences' theme, culture, genetic, and others. In fact, since the beginning, Goethe has introduced comparative literature under the name 'World Literature'. Goethe has said that one day, literature will unite and become a glorious union. It means every country's literature, even arts, will be united as world literature or world art.

According to Qian Zhongshu, comparative literature is one branch of science, which tries to compare literary works between countries and languages (Longxi, 1981). However, comparative literary research is no longer comparing literary works in one place but across languages and countries. Therefore, the comparative academic analysis is considered fascinating because it can explore the culture and way of thinking of other ethnic groups or other countries by comparing their art or literary works. Such as research comparing Indonesian and Chinese literary works that have been done by several researchers, as "Perbandingan Gambaran Tokoh Wanita Dalam Cerpen Kamar Kecil Di Gang Qingyuan dan Cerpen Bulan Sabit" by Aika Ramayu and Nurni Wahyu Wuryandari, "Analisis Perbandingan Tema pada Novel Hong Gaoliang Jiazu Karya Mo Yan dan Putri Melayu Karya Amiruddin Noor" by Iswandari, and Tengku Amira. Therefore, the research continues 
to open knowledge about the comparison of the movie to further research on comparing Indonesian and Chinese films.

The research also examines the history, geography, and politics so that there are differences and similarities between the two countries in viewing a hero's image. According to Ji Xianlin (Jiarong, 2004), comparative literature is comparing the two countries' literature that can be called comparative literature in the narrow definition. In a broad definition, comparative literature compares literary works with other branches of science, including comparing the humanities with social sciences, even compared to natural sciences. Therefore, it is clearer to understand the heroes' image in the two countries by looking at the extrinsic factors. Professor Yue Daiyun explains that comparative literature that emerged in the late 19th century is a branch of literary research in the early $20^{\text {th }}$ century. Comparative literature compares the historical process of two or more kinds of national literature, literature, and other art forms and relations between ideologies. Comparative literature is not the same as national literature, nor is it the same as general literature. Comparative literature does not examine a single type of national literature that continues to be related from generation to generation within its scope, nor does it discuss the same and general basic forms of world literature. Comparative literature is also not the same way as comparing literature in general. The end is to recognize phenomena as a way, but previously having its object, purpose, research scope, a standalone history of progress, and an independent research method (Jiarong, 2004). Therefore, the hero films in the two countries can compare the historical processes of the two countries. Besides, viewing movies from both countries has a clear goal, comparing thoughts and depictions of representation in films of the two countries.

Scholarly interest in representing culture in the literature between Indonesia and China has come a long way. Even more so, this effort to understand two countries' politics and culture manifests in a colored relationship with ups and downs. One of the efforts to restore relations between Indonesia and China is to conduct cultural research and intercultural communication. The cultural study is considered important because in facing the industrial era 5.0, the scope of intercultural interactions is increasingly unlimited. Intercultural communication is also important because it refers to the behavior and process of communicating and disseminating information among members of different cultural backgrounds (Lingling, 2020), like Indonesia and China. Moreover, with Indonesia's improvement and China's relations, a more in-depth cultural study is urgently needed. Studying a country's culture through movies, apart from understanding different cultures, defines and determines the representations, meanings, places, and functions of being heroes in their society. It would eliminate the intercultural communication gap resulting between Indonesia and China. Film as a cultural carrier is also an important medium to realize intercultural communication. It can reflect the values, thinking, the aesthetic orientation of a country, and at the same time, it has the responsibility of introducing foreign culture and spreading its own culture (Lingling, 2020). Based on the current background, this research's fundamental question is: what is a hero's image for the Indonesian and Chinese people is? This question also contains a more detailed question: how can the hero's image created by the film provide a view of each country's culture? Can the movies that appear provide more detailed information on the policies of each country? How can films strengthen the relationship between Indonesia and China?

Therefore, the research examines films presented in the 2000s that feature stories of struggles and figures of work. The film is a concept of the director's visual imagination, which actually attempts to legitimize the director's ideology. Besides, movies can also use social communication, advertisements, business transactions, political campaigns, academic seminars, art activities, and educational activities because films can effectively shape, direct, simultaneously contest, or destroy the image and understanding of reality (Nugroho, Adji, \& Wastiwi 2017). The research tries to put aside the reasons for making films with political interests, benefits, or other indoctrination elements. The primary purpose is to see the views of heroes from two countries. The films chosen are films that screened during the celebration of independence day and flicked with heroism. The research obtains further information about the similarities and differences between the two countries in viewing the image of heroes, ideology, and even the origin of the perspective on heroic culture.

The films in the research are based on true stories, not a movie with the theme of a fantasy story. The character represents elements that make a story worth mentioning, read, listen to, watch, and invite people to respond emotionally to that story's inner being (Fiky \& Lakoro, 2016). Therefore, real characters through the film can create a film with a message of heroism. Ten Indonesian films include Merah Putih, Gie, Susi Susanti, Soekarno, Tanah Surga Katanya, 3 Srikandi, Laskar Pemimpi, Guru Bangsa, Soegija, and Jenderal Soedirman. Ten China films include 攀登者 (The Climbers), 中国机长 (The Captain), 红海行动 (Operation Red Sea), 烈火英雄 (The Bravest), 战狼 1 (Wolf Warrior 1), 战狼 2 (Wolf Warrior 2), 建国大业 (The Founding of a Republic), 建党大业 (Beginning of The Great Revival), 建军大 业 (The Founding of An Army), 叶问 (IP Man). In this research, the story of the struggle of Indonesia and China in gaining independence can be seen from the film Merah Putih, Laskar Pemimpi, 建国大业 (The Founding of a Republic), 建党大业 (Beginning of The Great Revival), and 建军大业 (The Founding of An Army). The characters of freedom fighters recorded in visual media are seen in the film Gie, Soekarno, 叶问 (IP Man). Stories of struggles after the colonial period can see in movies Susi Susanti, 3 Srikandi, 攀登者 (The Climbers), 中国机长 (The Captain), 红海行动 
(Operation Red Sea), 烈火英雄 (The Bravest), 战狼1 (Wolf Warrior 1), 战狼2 (Wolf Warrior 2).

\section{METHODS}

The research applies a qualitative method using comparative literary theory to see the differences between the two countries in their overall view of the hero symbol. The data source used is the dialogue contained in ten Indonesian films, including Merah Putih, Gie, Susi Susanti, Soekarno, Tanah Surga Katanya, 3 Srikandi, Laskar Pemimpi, Guru Bangsa, Soegija, Jenderal Soedirman, and ten Chinese films such as 攀登者 (The Climbers), 中国机长 (The Captain), 红海行动 (Operation Red Sea), 烈火英雄 (The Bravest), 战狼 1 (Wolf Warrior 1), 战狼 2 (Wolf Warrior 2), 建国大业 (The Founding of A Republic), 建党大业 (Beginning of The Great Revival), 建军 大 业 (The Founding of An Army), 叶 问 (IP Man). The film data used are ten films with Indonesian subtitles and ten Chinese subtitles. The data analysis techniques are conducted by (1) determining the variable of film text data related to the theme of heroism, (2) classifying the data of the subtitles, (3) analyzing the data of the subtitles, and (4) drawing conclusions on the data of the subtitles.

\section{RESULTS AND DISCUSSIONS}

After observing 20 films of the Indonesian and Chinese struggles shown in the 2000s, the finding and discussion can be seen in Table 1 and 2 .

Table 1 Name and Theme of the Movies

\begin{tabular}{|c|c|c|}
\hline No & Movies & Theme \\
\hline 1. & Merah Putih & $\begin{array}{l}\text { Dutch military aggression } \\
\text { resistance in } 1947\end{array}$ \\
\hline 2. & Gie & $\begin{array}{l}\text { The story of Soe Hok Gie, a } \\
\text { bright student who was critical } \\
\text { of Soekarno's government } \\
\text { policies }\end{array}$ \\
\hline 3. & Susi Susanti & $\begin{array}{l}\text { Susi Susanti's struggle through } \\
\text { sports on the world stage with } \\
\text { domestic problems regarding } \\
\text { the Chinese ethnicity }\end{array}$ \\
\hline 4. & Soekarno & $\begin{array}{l}\text { The story of Soekarno and his } \\
\text { thoughts }\end{array}$ \\
\hline 5. & $\begin{array}{l}\text { Tanah Surga } \\
\text { Katanya }\end{array}$ & $\begin{array}{l}\text { The story on the border of } \\
\text { Kalimantan and Malaysia, as } \\
\text { well as conflicts of nationalism }\end{array}$ \\
\hline
\end{tabular}

Table 1 Name and Theme of the Movies (Continued)

\begin{tabular}{ccc}
\hline No & Movies & \multicolumn{1}{c}{ Theme } \\
\hline 6. & 3 Srikandi & $\begin{array}{l}\text { The story of three dart athletes } \\
\text { fighting for the glory of the } \\
\text { country through sports }\end{array}$
\end{tabular}

7. Laskar Pemimpi The second Dutch military aggression resistance in 1948

8. Guru Bangsa: The story of Tjokroaminoto Tjokroaminoto and his thoughts

9. Soegija The story of Pastor Soegija and his thoughts

10. Jenderal The story of General Soedirman Soedirman and his thoughts

11. 攀登者 In 1960, China was facing (The Climbers) a major disaster and facing border criticism about Qololangma (Everest) Mountain. A team of climbers from neighbouring countries prepared to climb from the south side, China decided to create a climbing team, and this was the first time the ascent to Mount Qololangma began rising from the north side

12. 中国机长 (The Captain)

The story of the damage Sichuan Airlines 8633 aircraft, which almost killed all crew and passengers on the plane

13. 红海行动 Rescue Chinese citizens in (Operation Red conflict countries

Sea)

14. 烈火英雄 (The Bravest)

The story of the firefighters

15. 战狼 1 (Wolf Warrior 1)

The Wolf Special Team training story

16. 战狼 2 (Wolf Warrior 2)

Retired Wolf Special Team named 冷锋 (Leng Feng) rescue Chinese citizens in conflict countries

17. 建国大业 The story of the independence (The Founding of of the People's Republic of a Republic) China

18. 建党大业 The story of the founding of (Beginning the Chinese Communist Party of The Great Revival)

19. 建军大业 The story of the formation of (The Founding of the Chinese Liberation Army An Army)

20. 叶问 The story of Ye Wen, a kung fu (IP Man) teacher during the struggle for independence 
Table 2 Movie's Important Dialogues

\begin{tabular}{cll}
\hline No & \multicolumn{1}{c}{ Movies } & \multicolumn{1}{c}{ Important Dialogue } \\
\hline 1. Merah Putih & $\begin{array}{l}\text { 16.31: When performing state duties, you are obliged to respect yourself. The task of this } \\
\text { unit, apart from Allah SWT, you must obey me. You don't act until you say you do. }\end{array}$ \\
2. Gie & $\begin{array}{l}\text { 51.07: Political parties and groups have entered the campus large student organizations } \\
\text { such as GMI, HMI, PMKR move on behalf of groups. I do not sympathize. I want to } \\
\text { see students who have political meaning, no matter how small, always based on mature } \\
\text { principles. They must have the courage to state that right is truth, wrong is wrong, and do } \\
\text { not apply the truth to any group, mass organization, or religion. } \\
\text { 08.11: Papi wants Susi to be the first Indonesian player to win a gold medal at the Olympics. }\end{array}$ \\
3. Susi Susanti & 100.01: I don't feel like an Indonesian, because I am an Indonesian. \\
& 16.01: A leader must be able to conquer the hearts of the people. People are as mysterious \\
as nature. If you can tie their hearts, they will follow you.
\end{tabular}
as nature. If you can tie their hearts, they will follow you.

120.01.34: A man who is close to the hearts of the people, whereas he is not.

5. Tanah Surga Katanya 12.43: What do you expect from the government? Do they never give anything to father who has fought on the border?

12.52: I serve not for the government, but this country, for my people.

6. 3 Srikandi

1:58 AM: I hate it when the sport is mixed up with politics, you should note it.

117.21: Continuing my dream 17 years ago to get a medal. But you have to remember, this medal is not for you, but your country.

7. Laskar Pemimpi

8. Guru Bangsa: Tjokroaminoto

9. Soegija

10. Jenderal Soedirman

1.21.46: We're getting rid of KNIL! In that case, my friends and I will hinder their movement, Sir!

22.51: Look at these workers. They are like worker ants who have lost their way. Since Prince Diponegoro, we have lost more than 70 years. We don't have a leader.

48.45: That's Tjokroaminoto, The Piningit Knight.

55.24: Long live Mr. Tjokro, Long live Haji Aminoeddin! Live the main!

1.03.08: Mr. Haendlift, times have changed; for today, we need someone like Tjokroaminoto to become a bridge for a future that is still unclear.

30.05: One hundred percent catholic, one hundred percent Indonesian.

40.00: Give this letter to Prime Minister Syahrir, asking Semarang to form a regional government, to overcome the disasters and chaos that occur the population. The situation cannot be allowed to drag on. I will try to make a truce as soon as possible.

5.00: As long as I was in the army, let alone elected to be commander-in-chief, my loyalty as commander-in-chief and his troops was absolute loyalty to the Soekarno-Hatta government. Suppose some soldiers try to overthrow the Syahrir government. In that case, our soldiers are not yet united, even though some of them deviate, my troops and I will support the legitimate government. Regarding the announcement to dissolve Syahrir's cabinet, it is tantamount to abusing his authority as commander-in-chief. And it never crossed my head once, which threatens to endanger the legitimate government.

1.39.12: (during the Syarikat Islam meeting, which was chaired by Agus Salim because Tjokroaminoto did not come) According to Mr. Tjokro, the most important thing is education.

11. 攀登者
(The Climbers)

12. 中国机长 (The Captain)
06.40: "Our mountain, we must be able to climb it, so that the whole world knows the Chinese people's power."

我们自己的山, 自己要登上去, 让全世界看到, 中国人!

07.5: Please trust us, we are trained professional

请相信我们, 我们受过专业的培训 
Table 2 Movie's Important Dialogues (Continued)

\begin{tabular}{|c|c|c|}
\hline No & Movies & Important Dialogue \\
\hline \multirow{11}{*}{13.} & & 机组能保证大家的安全 \\
\hline & 红海行动 & 45.40: "Not a single Chinese person should be hurt." \\
\hline & (Operation Red Sea) & 一个中国人都不能伤害 \\
\hline & & 76.30: "Eight against one hundred and fifty, have you had experiences like this before?" \\
\hline & & 8 对 150 , 你们以前有过这样的经验吗? \\
\hline & & $\begin{array}{l}\text { 76.35: "Our task is not to finish eight against one hundred and fifty, but to save the Chinese } \\
\text { who must be saved." }\end{array}$ \\
\hline & & 我们的任务不是要解决8比150, 而是去营救那个必须救得中国人质 \\
\hline & & 120.27: "Captain, the task is over!" \\
\hline & & 队长，任务完成了 \\
\hline & & $\begin{array}{l}\text { 135.29: "Attention, I am a Chinese naval soldier, you have entered China's territory, please } \\
\text { leave as soon as possible!" }\end{array}$ \\
\hline & & 注意, 我是中国海军你即将进入中国领海, 请立即离开! \\
\hline \multirow[t]{6}{*}{14.} & 烈火英雄 & 56.24: We will succeed, Sir! \\
\hline & & 保证完成任务! \\
\hline & & $\begin{array}{l}\text { 81.53: Get Up! Comrade Zheng Zhi has died, none of us wanted to see that happen, } \\
\text { however, in our line of duty, sacrifices are inevitable! }\end{array}$ \\
\hline & & $\begin{array}{l}\text { 站起来, 郑志同志牺牲了, 是我们不愿意看到的事情, 但是消防战斗早晚会有牺 } \\
\text { 牲。 }\end{array}$ \\
\hline & & $\begin{array}{l}\text { 114.04: I volunteer to join China Fire and rescue team, I pledge my loyalty to the party and } \\
\text { to strictly observe discipline. Serve the people against all the odds. }\end{array}$ \\
\hline & & $\begin{array}{l}\text { 我宣誓, 我志愿加入国家消防救援队伍, 对党忠诚, 纪律严明, 扑荡蹈火, 竭诚 } \\
\text { 为民。 }\end{array}$ \\
\hline \multirow[t]{8}{*}{15.} & $\begin{array}{l}\text { 战狼 } 1 \\
\text { (Wolf Warrior } 1)\end{array}$ & $\begin{array}{l}\text { 5.19: "How does it feel to kill people? I don't feel like I've killed people, I just feel like } \\
\text { I'm saving my friend. Saving a friend in times of struggle really feels extraordinary." }\end{array}$ \\
\hline & & 杀人什么感觉? 我没有杀人的感觉, 只有救人的感觉。救出战友感觉很爽 \\
\hline & & $\begin{array}{l}\text { 10.54: "Chinese? Don't underestimate the Chinese, when you meet him, you will find out } \\
\text { what you are dealing with ..... China, is a forbidden place for troops like you." }\end{array}$ \\
\hline & & $\begin{array}{l}\text { A Chinese guy? 不要小看中国, 当你遇到他的时候, 你就知道你面对的是什 } \\
\text { 么..... 中国, 那可是你们雇佣兵的禁地 }\end{array}$ \\
\hline & & $\begin{array}{l}\text { 19.54: "Do you know why we are called the wolf fighting squad? A wolf, is a pack animal, } \\
\text { one wolf will not win against a tiger or a lion, but if a group of wolves, in this world no one } \\
\text { can defeat him, so you have to cooperate with the troops, not just want to be great yourself, } \\
\text { puff out your own greatness." }\end{array}$ \\
\hline & & $\begin{array}{l}\text { 知道为什么我们叫战狼吗? 狼, 群体动物, 一头狼打不过一头狮或一头老虎, 可 } \\
\text { 是一群狼, 可以天下无敌, 要团队合作, 而不是一个人去英雄, 炫耀个人能力 }\end{array}$ \\
\hline & & $\begin{array}{l}\text { 83.09: "Every place has its own story, but anyone who tries to destroy China, to any extent } \\
\text { will be pursued." }\end{array}$ \\
\hline & & 每个地方都有故事, 犯我中华者, 虽远必诛 \\
\hline
\end{tabular}


Table 2 Movie's Important Dialogues (Continued)

\begin{tabular}{|c|c|c|}
\hline No & Movies & Important Dialogue \\
\hline 16. & $\begin{array}{l}\text { 战狼 } 2 \\
\text { (Wolf Warrior 2) }\end{array}$ & $\begin{array}{l}\text { 35.32: “Bring Dr. Chen and forty-seven Chinese citizens go home!” } \\
\text { 把陈博士和 } 47 \text { 中国同胞带回来 } \\
\text { 116.31: “To Chinese citizens: In times of trouble abroad, don’t despair! Remember, behind } \\
\text { you, there is a strong country that will protect you!” } \\
\text { 中华人民共和国公民: 当你在海外遭遇危险, 不要放弃! 请记住, 在你身后, 有 } \\
\text { 一个强大的祖国! }\end{array}$ \\
\hline 17. & $\begin{array}{l}\text { 建国大业 } \\
\text { (The Founding of a } \\
\text { Republic) }\end{array}$ & $\begin{array}{l}\text { 21.50: “If you save the land, you will lose the people. If you save the people, the land will } \\
\text { be safe too." } \\
\text { 存地失人, 人地谐失。存人失地, 人地谐存。 } \\
\text { 90.10: “The CCP follows the will of the people, then there will be results like this." } \\
\text { 中共顺应了民意，所以才有今天的成就. } \\
\text { 100.05: “China live long, China live long!” } \\
\text { 中国万岁，中国万岁! }\end{array}$ \\
\hline 18. & $\begin{array}{l}\text { 建党大业 } \\
\text { (Beginning of The } \\
\text { Great Revival) }\end{array}$ & $\begin{array}{l}\text { 73.22: “We are screaming for our four billion brothers!” } \\
\text { 我们是为了四万万同胞喊冤 }\end{array}$ \\
\hline 19. & $\begin{array}{l}\text { 建军大业 } \\
\text { (The Founding of an } \\
\text { Army) }\end{array}$ & $\begin{array}{l}\text { 124.24: “If there were them together, Zhu De, He Long, Ye Ting, Mao Zedong, then the } \\
\text { CCP will definitely have a future." } \\
\text { 有他们在一起（朱德、贺龙、叶挺、毛泽东）中共就有未来了 }\end{array}$ \\
\hline 20. & $\begin{array}{l}\text { 叶问 } 3 \\
\text { (IP Man 3) }\end{array}$ & $\begin{array}{l}\text { 76.17: Now I announce that I will challenge Ye Man publicly. } \\
\text { 我现在宣布, 我要公开挑战叶问. } \\
\text { 88.39: If I am not sick, would you go to the challenge? Yes } \\
\text { 如果我没有生病，你会不会去应战? 会 }\end{array}$ \\
\hline
\end{tabular}

From the 20 films' observations, the following data obtain five in the equation: patriotic spirit, nationalist spirit, brave and never give up, based on a true story theme, not fantasy, and character abilities that stand out because of experience and strong observation abilities. First, a patriotic attitude means love for the homeland. From patriotic spirit it will lead to patriotism in humans. Patriotism is the attitude of someone willing to sacrifice everything for his/her homeland's glory and prosperity (Sunendar, 2016) also the spirit of striving for the masses (Xiaoguang, 2018). The characters in these 20 films are ready to die and sacrifice for the country. For example, in the movie Soekarno, who was imprisoned many times, exiled, and finally struggled to negotiate with the Japanese, until he was considered a traitor and foreign stooge by other Indonesians, threatened the safety of Soekarno's family from the rampage of the masses. In the film “攀登者” (The Climbers), character 曲 松林Qu Songlin, for 13 years, with one of his legs disabled while climbing, continues to work as a trainer of climbers so that one day he can make amends for dropping the camera on the first climb. Second, the meaning of nationalist spirit is a lover of his homeland and his nation, a person who fights for his country's interests (Sunendar, 2016). Also, the appearance of figures depicts patriot images. In the main characters' dialects, the models' enthusiasm to achieve justice, the people's welfare, and the state can see the models' enthusiasm. As in the film Soegija, he has said: "Cut off my head first, then you can use it (church)." Also, in the film's 红海行动 (Operation Red Sea) dialect between characters to save Chinese citizens trapped in a conflicted country, "How can eight people face the coup army numbering one hundred and fifty," was answered by another figure, "We are not assigned in order eight against one hundred and fifty, we assigned to rescue the Chinese hostages." Third, the film heroes are bombarded continuously with suffering, hardship, and pain, but the characters never give up. The struggle for independence, saving someone's life, and the harrowing journey does not make these figures give up. As in the movie 战狼 2 (Wolf Warrior 2), although the character 冷锋 Leng Feng, in his rescue to a virus- 
prone and rebellious area, catches him with the virus and high fever, he still takes up arms to protect the population from rebel attacks. In the film Susi Susanti, although Susi's character lives under the pressure of a nationality conflict, being a nationalist or no, which is attractive because she is of Chinese descent, does not make her resign to make the red-white flag fly at the world championships. Fourth, these 20 films are based on true stories developed with fictional stories to add to the story's liveliness, like Soegija, the first indigenous pastor in the colonial era who carried out diplomacy Vatican's declaration of Indonesian independence. Soegija also sent writings abroad asking for support from Indonesia in the international community for the Dutch atrocities in 1947. The film 中国机长 (The Captain), which tells about the damage to the Sichuan Airlines aircraft 8633 on May 14, 2018, was theatrical. However, because of the skill of the crew, all passengers and crew survived. Lastly, Soe Hok Gie was a young Chinese figure, which was very bright in his time. His reading passion made him very observant at reading the political situation in Indonesia at a young age. The same as the movie Guru Bangsa: Tjokroaminoto, the warrior figure of Tjokroaminoto is like a light in Indonesian youth's gloom during the colonial period. His critical character made him often punished from his childhood for his logic about the Dutch colonialists who exploited Indonesian resources. In the film 叶问 (IP Man), Ye Wen uses kung fu to protect the Chinese people's colonial atrocities. Meanwhile, in the movie 建党大业 (Beginning of the Great Revival), the character 毛泽东 Mao Zedong、周恩来Zhou Enlai、 孙中山 Sun Yatsen, and other characters have vital observations, are critical, like to read, and are good at reading situations in their time.

Base on the research, it indicates Indonesian and Chinese films both looking at the image of a hero, theme, form of struggle, depicting characterization, the hero's character, and the message written in the film have significant differences. First, the themes raised in Indonesian and Chinese films have striking differences. Indonesian and Chinese movies, although several films tell the history of the struggle for national independence, Indonesian films emphasize more actual domestic problems. As in the movie Soekarno, the theme of gender (oppression of women) shows how painful it is for a woman who is destined to have no children and then has to sacrifice to be ready to accept her husband's marriage to another woman. Also, the emergence of the hero Soegija, who fought in the name of Catholicism. Another noticeable thing is the raising of tribal conflicts that have occurred in Indonesia. How does a world hero Susi Susanti have to face the conflict over PP's impact? PP No. 10 of 1959 is Presidential Decree Number 240 of 1967 and all kinds of state regulations regarding their status as citizens of Chinese descent. Chinese films that tell heroism stories are not full of themes of 'protest' to domestic problems. The films that were born only tell stories about history, loyalty to the country, and the community's courage in helping victims of natural disasters. China's slogan literature and art serve the workers, serving the proletariat 文艺为工农兵服 务, 为无产阶级服务 in film creation are closely combined with the social process (Yumei, 2020) that becomes materialized. Second, in 20 Indonesian and Chinese films, it can be seen clearly that the main characters (heroes) in the movie have different ways of struggling. Ye Wen struggles as the main character in the film IP Man; although he works alone, he struggles to fight to protect his kung fu school's dignity. In the movie Soekarno, it is told about their struggle; Soekarno and Hatta struggle individually to cooperate with the Japanese. Soekarno was considered a traitor and foreign stooge by the community. After Japan lost to the Allies, the youths forced Soekarno to declare Indonesia's independence immediately. $\mathrm{He}$ refused, so he was kidnapped by another young man to Rangkas Bitung. From the emergence of the conflicts that have emerged, it can be seen that the image of heroes in Indonesian films is personal, while Chinese films are collective. Therefore, Chinese films reflect the altruistic characteristic of Chinese socialism (Bo \& Fei, 2019).

Table 3 Movie's Different Points

\begin{tabular}{|c|c|c|c|}
\hline No & Movies & Indonesia & China \\
\hline 1. & Main theme & $\begin{array}{l}\text { Against colonialism, against gender } \\
\text { injustice, class, ethnicity }\end{array}$ & Against colonial, feudal, disaster relief \\
\hline 2. & Idea/form of struggle & Personal & Group \\
\hline 3. & $\begin{array}{l}\text { Hero's standing/viewing } \\
\text { overview }\end{array}$ & $\begin{array}{l}\text { Emphasizes personal views, family } \\
\text { (group) responsibilities }\end{array}$ & $\begin{array}{l}\text { Shouldering the task of the state (group) } \\
\text { in general }\end{array}$ \\
\hline 4. & Hero traits & $\begin{array}{l}\text { Besides being serious, smart, intelligent, } \\
\text { mature, but also sometimes humorous, } \\
\text { dynamic }\end{array}$ & Serious, smart, mature \\
\hline 5. & Explicit message & $\begin{array}{l}\text { Emphasizing domestic problems, border } \\
\text { conflicts, and economic hardships made } \\
\text { sense of patriotism and nationalism } \\
\text { disappear. }\end{array}$ & $\begin{array}{l}\text { Showing the greatness of the Chinese } \\
\text { Country, the film gives a message to } \\
\text { foreign audiences, in particular, to not } \\
\text { disturb China's territory. }\end{array}$ \\
\hline
\end{tabular}


Third, the characters in the film can easily see it from the dialogue that appears. Like Soe Hok Gie's dialogue in the movie, "Political parties and groups have entered the campus, large student organizations such as GMNI, HMI, PMKRI move on behalf of groups, I do not sympathize. I want to see students make decisions that contain political meaning, no matter how small, based on mature principles. They must have the courage to say that right is the truth, and wrong is wrong, and does not apply the truth to groups, mass organizations, or religion wherever." The main character in the film Guru Bangsa: Tjokroaminoto says, "I, Oemar Said Tjokroaminoto, a native Muslim fighter and chairman of the Sarekat Islam which has two million members of the largest association in East Java, understand the law, I am the first member of the Volksraad, my grandfather Adipati Tjokronegoro has served as Ponorogo's regent, my grandfather from the other side Kyai Kasan Besari, is a famous Kyai who taught me about the value of life as a Javanese." In the films 中国机长 (The Captain), the cabin crews have said, "Please trust us, we are trained professional." 攀登者 (The Climber), there is a dialogue, "Our own mountain, we must be able to climb it so that the whole world knows, the power of the Chinese people." It can be seen; clearly, the characters Soe Hok Gie and Tjokroaminoto put forward thoughts and responsibilities as 'I', while the characters in 中 国机长 (The Captain) and 攀登者 (The Climber) put forward 'us/our' in carrying out their duties. Fourth, Indonesia and China are on the same continent, namely the Asian continent. A long and dark historical story due to colonialism has provided an extraordinary story to the world. In terms of the hero and storytelling character, there is a marked difference in the heroes. In Indonesian and Chinese films, heroes are always depicted as having severe, intelligent, and mature traits. However, in Indonesian cinema, heroes are shown as having dynamic characteristics, while the Chinese are not. The film Laskar Pemimpi tells of a humorous hero, also in the movie, Soegija and Jenderal Soedirman appear as innocent characters. These are to give the audience a sense of humor. Fifth, in the film Bumi Surga Katanya, the explicit message talks about Indonesia's complicated problems with Malaysia's border, such as many Indonesian citizens who have moved Malaysian citizenship due to economic pressure. The Ringgit currency uses in Indonesia and the lack of nationalism towards Indonesia by not knowing it. People on the border are against the red and white flag. Other implicit messages in the film are also present, such as reading poetry satiating the corruptors, grandfather Salman's loyalty to Indonesia even though the government does not pay attention. If Indonesian films contain 'criticism' of Indonesia's domestic problems, Chinese films seem to provide 'criticism' to other countries not to disturb China's territory. It is seen from the film 红 海行动 (Operation Red Sea), which shows the strength of the Chinese naval fleet, as well as 攀登者 (The Climbers), which tries to tell the world the greatness of Chinese climbing forces in terms of physical and technological terms in climbing the Himalayas. This message is clear, providing information to viewers and other countries that China's territorial territory should not be contested. It is a dead card.

The researcher tries to dig deeper into several points of view about the differences in culture and how the image of heroes between Indonesia and China has occurred. First, the research tries to conclude from historical and geographical factors points of view. Indonesia is an archipelagic country so that each community has a very different character. Therefore, it is not easy for a country with more than three hundred ethnic groups to have the same concept of leaders and heroes. Then, Indonesia is a divine and democratic country. Therefore, people often obey religious leaders rather than the central government. The hero's image in the film also puts forward thoughts of the character and the group. China, since the Tang dynasty, was a country with a vast population. Therefore, education since childhood has been instilled to live in groups and live for the kingdom (land). Chinese society does not prioritize individual life but puts forward collective experience. Chinese society's traditions live under a central feudal system for five thousand years, making them passive people, not deserving of personal glory. According to Chinese culture, praise and truth belong to the king. Therefore, this characteristic brings Chinese society to become a collective figure. Everything is done based on orders from the higher-ups, not on their own accord. Second, from the interpretation of the meaning of patriotism point of view. In the interpretation of the meaning, understanding patriotism for the people of Indonesia and China is different. For the Indonesian people, everyone can become a hero, personal characteristics or being a hero can be done to defend the group. For Chinese people, the notion of a hero is a person who has completed tasks and fought for the country. Third, from a cultural perspective, Indonesian society's culture has been promoting personal space since ancient times. The form of communication in Indonesian society is also private so that everyone is given the freedom to express their opinions. At the same time, they do not conflict with religious and customary ethics. The communication culture of Chinese society is like a 'cobweb', such as the education applied in China since thousands of years ago by Confucius with his book Zhongyong (中庸: “天下之达道五, 所以行之者三, 日君臣 也, 父子也, 夫妻也, 昆第也, 朋友之交也, 五 者, 天下之达道也, 知, 仁, 勇, 三者, 天下之 达德也, 所以行者一也。The duties of universal obligation are five, and virtues wherewith they are practiced are three). The Zhongyong means the life of one person must be related to many people. Therefore, any decision-making for the Chinese people always puts the interests of many people first. Confucianism has influenced Chinese traditional culture for a long time. For Confucianism, ethics as the center, social class as the basis, social governance based on 'rule of rites' and 'power of virtue, supplemented by law rule, it advocates that sages decide on rites and laws 
and believes that they are upright and do not obey orders (Yuan, 2019). Therefore, a character in the film dedicated to the country appears and does not leave a single Chinese person in a state in conflict. Fourth, from the political issues point of view, such as in Tanah Surga Katanya, the hero figure is a veteran figure who is still faithfully living in Indonesia. He could easily change nationalities to improve his life, but he refused in the name of nationalism. In the example of this film, it can be seen that Indonesia is still experiencing complex economic problems, national defense, and state management in dealing with areas far from the capital. In Chinese films, being a hero is a character who can protect all Chinese society, even abroad, for example, in times of disaster. Besides, for Chinese people, a hero is a figure who can protect China's borders from foreign attacks, as in the film 《红海 行动》(Operation Red Sea), which is a reflection of China's maritime border conflicts with other countries.

\section{CONCLUSIONS}

The hero's image in Indonesian and Chinese films has different geographic, cultural, ideology, and political issues, giving rise to a unique heroic story in the two countries' films. These films teach that there are still many unresolved tasks and homework, both domestic and foreign conflicts. Therefore, it can open up new scientific horizons to know each other's culture and political policies by comparing Indonesian and Chinese films. Understanding the cultures of other nations through films can help strengthen relations between the two countries moreover, the problem of foreign policy that appears in the movies.

\section{REFERENCES}

Azri, B., Y., \& Agung, I., M. (2017). Pahlawan: Siapa mereka? Pendekatan psikologi indigenous. Jurnal Psikologi Sosial, 15(2), 95-104. http://doi. org/10.7454/jps.2017.9.

Bin, R. (2020). Presenting the new epic of the Chinese nation with movies. Home Drama, 9, 101.

Bo, P., \& Fei, J. (2019). Group of images of new heroism in "The Captain". XIBU GUANGBO DIANSHI, 23, 120.

Chao, Zhang. (2019). The Image of "Hero" in Western China Movies. Arts Criticism, 3, 105-110. http://doi. org/10.16364/j.cnki.cn11-4907/j.2019.03.017.

Fan, Z., \& Yuanyuan, S. (2019). Challenging spirit and hero narration - Theme implication and enlightenment of "The Captain" movies. Art Review Journal, 11, 164-170. http://doi.org/10.16364/j.cnki.cn114907/j.2019.11.019.

Fiky, M., \& Lakoro, R. (2016). Perancangan karakter serial animasi 3D "Sanggramawijaya" dengan studi archetype adaptasi literatur tokoh film action lokal Indonesia. Jurnal Sains dan Seni ITS, 5(2), 204-208. http://doi.org/10.12962/j23373520.v5i2.20540.
Hui, F. (2018). A comparative study of heroism in Chinese and American films. Overseas English, 10, 167. http://doi.org/CNKI:SUN:HWYY.0.2018-19-080.

Jiarong, W. (2004). New edition of comparative literature. Mainland China: Anhui Education Press.

Jingjing, L., \& Hua, S. (2018). A comparative study of Hua Mulan series movies between China and The United States from the perspective of heroism. Crazy English (Teachers), 3. http://doi.org/10.3969/j. isss.1006-2831.2018.03.061.

Lingling, D. (2020). The cultural innovation of Chinese films from the perspective of intercultural communication. Movie Literature, 11(752), 52-54.

Longxi, Z. (1981). Qian Zhongshu on comparative literature and literary comparison. Read Journal, 10, 132-138. http://doi.org/CNKI:SUN:DSZZ.0.1981-10-032.

Nugroho, W., Adji, T., S., \& Wastiwi, S. (2017). Proses kreatif Eddie Cahyono dalam penciptaan film "Siti". Capture: Jurnal Seni Media Rekam, 8(2), 75-89. https://doi.org/10.33153/capture.v8i2.2049.

Pratama, D., Wardani, W. G. W., \& Akbar, T. (2017). Designing visual character of Raden Wijaya as historical figure in visual novel. International Journal of Scientific \& Technology Research, 6(11), 207-210.

Putri, I. P., Nuraeni, R. M. C., \& Syahriar, S. M. (2017). Industri film Indonesia sebagai bagian dari Industri Kreatif Indonesia. Jurnal Liski, 3(1), 24-42. https:// doi.org/10.25124/liski.v3i1.805.

Saptanto, D. D., \& Dewi, M. K. (2020). Gundala and Gatotkaca in the concept of modern Indonesian superheroes: Comparative analysis of the Indonesian and American superheroes. Edulite: Journal of English Education, Literature, and Culture, 5(1), 136-147. http://dx.doi.org/10.30659/e.5.1.136-147.

Sunendar, D. (2016). Kamus besar bahasa Indonesia. Jakarta: Balai Pustaka.

Xiaoguang, Y. (2018). Calling for "New Heroes": On the cultural change and motivation of early Chinese movies. Modern Communication, 3, 103-109.

Yigu, X. (2016). A comparative study of Chinese and American films from the perspective of heroism. XIJUZHIJIA, 7, 99-102. http://doi.org/10.3969/j. issn.1007-0125.2016.04.072.

Yong, T. (2019). Defending and inheriting: The contemporary value and realization path of heroic spirit. Studies in Ideological Education, 2, 101-105. http://doi.org/ CNKI:SUN:SIXI.0.2019-02-021.

Yuan, P. (2019). The origin of movie's ethics from the perspective of comparison between China and the West. Yishu Pinglun, 7, 65-78. http://doi. org/10.16364/j.cnki.cn11-4907/j.2019.07.009.

Yumei, X. (2020). Three turns of hero narration in China's new movies decade. Movie Literature, 5(746), 5.

中国社会科学院语言研究所词典编辑室. (2016). 现代 汉语词典 Modern Chinese Dictionary ( $7^{\text {th }}$ Ed.). Beijing: The Commercial Press.

汉语大辞典 Chinese Dictionary Online. http://www. hydcd.com. 